\title{
FENOMENA KENAKALAN REMAJA DALAM PERSPEKTIF PSIKOLOGI PENDIDIKAN ISLAM (Studi Kasus Penganiayaan yang Menyebabkan Kematian di Dusun Kayunan Kabupaten Sleman)
}

\author{
Ainy Kartika \\ Program Studi Psikologi Pendidikan Islam \\ Program Pasca Sarjana \\ Universitas Muhammadiyah Yogyakarta \\ E-mail: ainikartikakahfi@gmail.com
}

\begin{abstract}
Abstrak
Penelitian ini bertujuan untuk mengetahui fenomena perilaku kenakalan remaja dan mengetahui faktor-faktor penyebab terjadinya kasus penganiayaan yang menyebabkan kematian di Dusun Kayunan Kabupaten Sleman. Jenis penelitian ini adalah studi kasus dengan pendekatan deskriptif kualitatif. Lokasi penelitian adalah Dusun Kayunan Desa Donoharjo Kecamatan Ngaglik Kabupaten Sleman Propinsi DIY. Teknik pengumpulan data melalui wawancara mendalam dan dokumentasi. Kesimpulan penelitian ini adalah: perilaku menganiaya yang mengakibatkan kematian menunjukkan bahwa para remaja belum mencapai tingkat pascakonvensional dalam perkembangan penalaran moral Kohlberg. Faktor-faktor penyebab para remaja melakukan tindak pidana penganiayaan yang mengakibatkan kematian adalah faktor eksternal berupa intoksikasi minuman keras, pengaruh teman sebaya, pengaruh pola asuh orangtua dan pengaruh lingkungan buruk. Sedangkan faktor internal berupa perkembangan karakteristik usia remaja, serta pengaruh perkembangan kepribadian remaja yang merupakan bentukan pada masa anak-anak yang dipengaruhi oleh lingkungannya.
\end{abstract}

Kata kunci: kenakalan remaja, psikologi pendidikan Islam

\begin{abstract}
This study aims to investigate the phenomenon of juvenile delinquency and factors that lead to the cases of fatal abuses in Kayunan Village in Sleman District. This is a descriptive qualitative case study, and its research is carried out in of Kayunan, Donoharjo Village, Ngaglik sub-districy, Sleman district, Yogyakarta. Data collection was by in-depth interviews and trough documentation. Data analysis leads the investigator to the following conclusions. Acts of fatal abuse indicate an arrest in the moral development of the juvenile perpetrators, in that they have not reached the post conventional stage in Kohlberg's theory of moral development. Factors that have led the teenagers to commit fatal abuses include alcohol intoxication, parenting practices, laxity in social and community control over juvenile delinquency. Other factors are internal in nature, such as the teenagers' personality development, as well personality development which bears certain traits shaped during childhood.

Key words: juvenile delinquency, Islamic education psychology
\end{abstract}

\section{Info Artikel}

Diterima September 2017, disetujui Oktober 2017, diterbitkan Desember 2017 


\section{PENDAHULUAN}

Secara psikologis, perilaku bermasalah remaja adalah perilaku yang merupakan akibat dari adanya berbagai perubahan fisik dan psikis dalam pertumbuhan dan perkembangan. Tetapi perilaku tersebut telah menunjukkan berbagai tanda yang mengarah pada adanya penyimpangan yang cenderung merugikan diri sendiri dan lingkungannya. Perilaku ini juga merupakan pengembanganpengembangan negatif berbagai masalah wajar sebelumnya yang semakin menguat yang diakibatkan oleh tiga hal; pertama, dirinya kurang mampu menyesuaikan diri dengan pertumbuhan dan perkembangannya serta tidak mampu menerima apa yang diraihnya. Kedua, adanya berbagai tekanan lingkungan, seperti dari orangtua dan teman sebaya serta masyarakat yang lebih luas. Ketiga, tidak mampu menyesuaikan diri dengan berbagai tekanan yang ada. Demikian menurut Mighwar (2011: 191).

Selain itu, fitriyah (2014: 5) menyebutkan, meluasnya arena mobilitas sosial juga berkontribusi menjadi penyebab tekanan yang dialami remaja. Jika remaja berhasil melampaui tekanan-tekanan biologis dari dalam dirinya dan tekanan sosiopsikologis dari lingkungan sosialnya, maka dimungkinkan akan dapat memasuki masa dewasa dengan penuh kemandirian dan tanggungjawab. Sebaliknya jika gagal, maka selanjutnya akan mengalami banyak kesulitan untuk mencapai kedewasaan, hal ini memungkinkan remaja untuk melakukan perilaku destruktif yang dapat merusak dan menyakiti dirinya sendiri maupun orang lain.

Dalam bukunya Patologi Sosial 2, Kartini Kartono (2014: 4) mengatakan, erbagai tingkah laku yang sakit secara sosial tadi merupakan penyimpangan sosial yang sukar diorganisir, sulit diatur dan ditertibkan, sebab para pelakunya memakai cara pemecahan sendiri yang nonkonvensional, tidak umum, luar biasa atau abnormal sifatnya. Biasanya mereka mengikuti kemauan dan cara sendiri demi kepentingan pribadi. Karena itu deviasi tingkah laku tersebut dapat mengganggu dan merugikan subyek pelaku sendiri dan atau masyarakat luas. Deviasi tingkah laku ini juga merupakan gejala yang menyimpang dari ciri-ciri umum rakyat kebanyakan, bertentangan dengan hukum atau melanggar peraturan formal.

Menurut sumber informasi dari BPS Yogyakarta terkait kenakalan remaja, disebutkan bahwa jika diamati berdasarkan jenis kejahatan, Kabupaten Sleman memiliki jumlah desa terbanyak mengalami berbagai jenis tindak kejahatan di banding kabupaten/kota lain. Termasuk Kecamatan Ngaglik. Bila dilihat menurut jam terjadinya tindak kejahatan, di semua kabupaten di Provinsi D.I. Yogyakarta pada umumnya tindak kejahatan banyak 
terjadi pada range waktu pukul 18.0023.59 dan pukul 00.00-05.59. Sedangkan untuk Kota Yogyakarta lebih banyak terjadi pada pukul 18.0023.59 dan pukul 06.00-11.59.

Perhatian pemerintah maupun masyarakat perlu ditingkatkan, karena di Provinsi D.I.Yogyakarta terdapat 13,47 persen desa/kelurahan mengalami tindak kejahatan "Penyalahgunaan/Pengedaran

Narkoba". Jika diamati berdasarkan jenis kejahatan, Kabupaten Sleman memiliki jumlah desa terbanyak mengalami berbagai jenis tindak kejahatan di banding kabupaten/kota lain. Hal lain yang cukup memprihatinkan adalah adanya perkelahian massal. Menurut hasil Podes 2011 di Provinsi D.I.Yogyakarta perkelahian massal terjadi di 13 desa/kelurahan. Angka perkelahian massal tertinggi adalah pada jenis perkelahian antar pelajar/mahasiswa. Kasus tersebut terjadi di 8 desa/kelurahan. Peringkat selanjutnya adalah perkelahian antar kelompok.

Beberapa kasus yang memberikan gambaran tentang tingkat kenakalan remaja di wilayah Yogyakarta menunjukkan bahwa hampir di setiap Kabupaten ditemukan kasus klithih. Di Gunungkidul misalnya, penggerebekan oleh aparat keamanan terhadap geng remaja juga menyita barang bukti berupa pedang, botol-botol minuman keras dan beberapa senjata tumpul. Demikian juga di Bantul, dengan modus yang hampir sama terjadi di Padukuhan Terong Dlingo Bantul, belasan remaja menggreber motor dan menyerang warga dengan melempari kerikil dan menyabetkan pedang tanpa sebab. Selain itu, kekerasan di antara remaja, yaitu dua siswa sekolah swasta di Bantul dan seorang siswa SMA Negeri di Bantul dalam kasus pemukulan dengan stik terhadap siswa SMK Muhammadiyah 1 Bambanglipuro. Sementara itu, di Sleman dalam sehari yaitu pada Jumat (21/4/2017) dini hari terjadi dua kasus klithih, seorang tukang ojek online dan satu lagi seorang anggota polisi disabet senjata tajam.

Data Reserse dan Kriminal Polsek Ngaglik menyebutkan beberapa kasus yang terjadi di sekitar daerah Ngaglik dalam dua tahun terakhir di antaranya berhasil menangkap dua pelaku kekerasan jalanan atau yang kerap disebut klitih. Dari sepuluh orang gerombolan yang diketahui melakukan aksi kekerasan dengan membacok seorang remaja bernama Nur Cahyo (19 tahun) warga Tegalrejo, Sariharjo, Ngaglik, polisi berhasil mengamankan dua pelaku yaitu Febri, 23 warga Sariharjo, dan Randika, 18, warga Sendangadi, Mlati, Sleman, setelah melalui penyelidikan selama beberapa hari. Dalam penyelidikan tersebut polisi juga menemukan barang bukti berupa motor Kawasaki KLX hitam dan pedang. Menurut keterangan pelaku, saat kejadian mereka memang terpengaruh minuman keras. 
Informasi terbaru kasus klithih yang terjadi terhadap remaja Dusun Kayunan yang bernama Fathoni terjadi pada bulan April 2017. Informasi ini peneliti dapatkan secara langsung dari korban. Korban saat itu sedang melintasi jalan Damai bersama beberapa temannya, kemudian secara tiba-tiba diserang dengan senapan angin yang kemudian mengenai mata, telinga dan kepala bagian belakang.

Memahami

adanya

kesenjangan antara realitas remaja saat ini dan idealitas eksistensi diri remaja, maka peneliti berkesimpulan bahwa masalah ini sangat perlu dikaji. Perilaku agresif pada berbagai peristiwa penganiayaan yang menyebabkan kematian (di Yogyakarta dikenal dengan istilah klithih), merupakan salah satu contoh dari fenomena yang sudah sedemikian meresahkan ini.

\section{KAJIAN TEORI}

\section{Teori Perkembangan Moral} Kohlberg

$\begin{array}{lrr}\text { Teori } & \text { Kohlberg } & \text { tentang } \\ \text { perkembangan } & \text { moral } & \text { merupakan } \\ \text { perluasan, modifikasi dan } & \text { redefenisi } \\ \text { atas teori } & \text { Piaget. } & \text { Kohlberg }\end{array}$ mengklasifikasikan perkembangan moral atas tiga tingkatan (level), yang kemudian dibagi lagi menjadi enam tahap (stage). Semakin tinggi tahap perkembangan moral seseorang, akan semakin terlihat moralitas yang lebih mantap dan bertanggung jawab dari perbuatan-perbuatannya. Dengan demikian, orang yang bertindak sesuai dengan moral adalah orang yang mendasarkan tindakannya atas penilaian baik-buruknya sesuatu.

Secara singkat perspektif sosial dan ciri penalaran moral tiap-tiap tingkatan diungkapkan oleh Arbuthnot dan Faust (1981, hal. 49-50) sebagai berikut:

1. Tingkatan prakonvensional, yang mempunyai ciri-ciri bahwa apa yang benar atau salah itu terbatas pada aturan-aturan konkrit atau atas dasar kekuasaan atau hukuman. Bila tidak ada aturannya, yang benar adalah yang sesuai dengan interes diri saja atau interes orang lain saja.

2. Tingkatan konvensional, yang benar adalah yang sesuai dengan harapan masyarakat atau kelompok tertentu mengenai perilaku yang "baik". Seseorang yang ada pada tahap ini sangat memperhatikan aturan-aturan sosial, harapan-harapan, serta peran-peran. Tindakan yang dianggap benar dilakukan karena adanya motivasi yang ada dalam diri seseorang untuk melakukan apa yang diterima dan diharapkan oleh masyarakat.

3. Tingkatan pascakonvensional, yang "benar" didefinisikan atas dasar hak asasi manusia yang umum dan universal, nilai-nilai atau prinsip-prinsip yang wajib digunakan baik oleh masyarakat maupun individu. Seseorang yang berada pada tahap ini percaya bahwa sebagai anggota masyarakat 
harus membuat kontrak untuk menjamin hak dari semua anggotanya, dan harus bertingkah laku sesuai dengan prinsip nilai etis yang akan diakui oleh setiap orang yang bermoral.

\section{Masa Baligh dan Tanggung Jawab Moral Remaja}

Baligh adalah anak yang sudah mencapai usia yang mengalihkannya dari masa kanak-kanak (thufulah) menuju masa kedewasaan (rujulah/unutsah). Masa ini biasanya ditandai dengan nampaknya beberapa tanda-tanda fisik, seperti mimpi basah (ihtilam), mengandung dan haidh. Dan apabila tanda-tanda tersebut tidak nampak, maka masa baligh ditandai dengan sampainya seorang anak pada umur 15 tahun menurut pendapat madzhab Syafi'i. Pada masa ini perkembangan tubuh dan akal seorang anak telah mencapai kesempurnaan, sehingga ia diperkenankan melakukan berbagai tashorruf secara menyeluruh (ahlul 'ada' al-kamilah).

Kata baligh dalam Alquran digunakan dalam konteks apa yang dibicarakan. Paling tidak terdapat dua kata baligh yang ada di dalam Alquran, yaitu QS. An-Nisaa': 6 dan QS. Al-Ahqaf:15.

"Dan ujilah anak yatim itu sampai mereka cukup umur untuk kawin. Kemudian jika menurut pendapatmu mereka telah cerdas (pandai memelihara harta), maka serahkanlah kepada mereka hartanya. Dan janganlah kamu makan harta anak yatim lebih dari batas kepatutan dan (janganlah kamu) tergesa-gesa (membelanjakannya) sebelum mereka dewasa...." [QS. AlNisa: 6]. Ayat tersebut menjelaskan bahwa waktu yang tepat dalam rangka menyerahkan harta kekayaan anak yatim dari harta tinggalan orang tuanya yang telah wafat, terlebih dahulu dilihat apakah dia sudah cukup cerdas atau matang pemikirannya sehingga sanggup memelihara harta atau tidak. Kalau kita simak ayat tersebut, terdapat kata baligh yang digunakan dalam konteks membicarakan seseorang yang cukup umur untuk kawin. Lalu dilanjutkan dengan penjelasan bahwa indikasi cukup umur untuk kawin adalah dengan adanya kecerdasan dan kecakapan seseorang dalam mengelola keuangan, yang disebut dengan rusyd. Memang rusyd dalam Alquran tidak dibatasi oleh usia tertentu. Hanya terdapat indikasi-indikasi dan tandatanda seperti sudah mempunyai kepribadian yang dewasa, punya kemandirian sikap, dan mampu mengatur ekonomi dan mengatur diri sendiri.

Fase rusyd adalah fase pascabaligh, disebut dengan bulugh sinni al-rusyd (telah tiba saatnya pada usia matang). Rusyd juga tergolong baligh dalam terminologi Alquran, yaitu bulugh sinn al-rusyd (usia matang). Memang usia matang dalam Islam tidak ditentukan pada usia berapa seseorang disebut dengan usia matang itu. Akan tetapi kalau memang as-Syafi' $i$ menentukan usia baligh fisik 
biologis adalah 15 tahun, dan $\mathrm{Abu}$ Hanifah menentukan usia baligh fisik biologis adalah 17 tahun bagi perempuan dan 18 tahun bagi lelaki. Maka usia matang (rusyd) itu berarti kalau menurut as-Syafi' $i$ adalah pasca usia 15 tahun dan menurut $\mathrm{Abu}$ Hanifah adalah pasca usia 17 tahun bagi perempuan dan 18 tahun bagi lelaki. Natsir (2015: 7)

\section{Anggapan Keliru Tentang Masa Remaja}

Zakiah Darajat (1995: 10) menulis, "Istilah remaja atau kata yang berarti remaja tidak ada dalam Islam. Di dalam Al-Quran ada kata alfityatu, fityatun yang berarti orang muda." Kemudian Dr. Zakiah mengutif surah Al-Kahfi ayat 10 dan 13, serta surah An-Nuur ayat 58 dan 59, dan berkata, "Tampaknya masa remaja, yang mengantarai masa kanak-kanak dan dewasa, tidak terdapat dalam Islam. Dalam Islam seorang manusia bila telah aqil baligh, telah bertanggung jawab atas setiap perbuatannya. Jika ia berbuat baik akan mendapat pahala, dan bila melakukan perbuatan tidak baik akan berdosa.

\section{Fauzil}

Adhim

(2017)

mengatakan bahwa masyarakat beranggapan, masa remaja adalah masa yang wajar dipenuhi dengan krisis identitas dan turbulensi. Seolaholah setiap remaja wajib mengalaminya. Padahal, sebenarnya cuma 1 dari 5 remaja bersekolah di seluruh dunia yang mengalami krisis identitas (Offer \& Schonert-Reichl, 1992). Artinya, $80 \%$ remaja bersekolah tidak mengalami krisis. Jika kita menelaah berbagai literatur psikologi, sebenarnya kondisi remaja berkaitan dengan identitas dirinya itu ada empat macam. Pertama, remaja paripurna, yakni remaja yang semenjak kecil tidak mengalami krisis dan mereka mempunyai arah yang jelas. Mereka dapat mencapai keadaan yang seperti ini karena terinspirasi oleh sikap dan keyakinan orangtua. Kedua, remaja yang sempat mengalami krisis identitas, tetapi dapat segera keluar dari krisis. Ini pun juga banyak dipengaruhi oleh peran orangtua. Ketiga, remaja yang meninggalkan masa kanak-kanak dengan krisis identitas yang serius. Krisis itu bahkan dapat terjadi di akhir masa kanak-kanak. Mereka inilah yang memerlukan pendampingan, dari orangtua dan guru maupun teman sebaya yang sudah memiliki kematangan pribadi. Guru BK perlu proaktif menggugah minat dan membangkitkan keinginan untuk menjadi yang terbaik, bukan sekedar menjadi bagian reserse kriminal di sekolah yang bertugas memanggili anak-anak bermasalah. Keempat, remaja yang identitas dirinya mengambang. Belum punya arah yang kokoh, tetapi tidak sedang mengalami keguncangan maupun krisis identitas, dan tidak punya gairah untuk sukses; tidak ada keinginan sangat kuat untuk meraih yang terbaik. Keinginan selintas boleh jadi ada atau sering ada, 
tetapi tidak memperoleh umpan balik dari lingkungan yang membersamai tumbuh-kembangnya setiap hari. Jika ia tinggal di rumah, maka itu adalah orangtua. Jika ia tinggal di asrama, itu adalah warga asrama dan pembimbingnya.

\section{Hakikat Pemuda dalam Islam: Kritik Terhadap Makna Murahaqah}

Murahaqah atau remaja dalam terminologi psikologi umum, menurut Al-Mighwar (2011: 55) berarti mendekati kematangan secara fisik, akal, jiwa serta sosial. Murahaqoh juga bermakna at-tadarruj (berangsurangsur). Jadi, artinya adalah berangsur-angsur menuju kematangan secara fisik, akal, kejiwaan, dan sosial serta emosional.

Namun makna ini sangat berbeda dengan pemikiran yang disampaikan DR. Khalid Ahmad Asy Syantut dalam bukunya yang berjudul Tarbiyah Asy Syabab Al Muslim lil Aba' wad Du'at (Pendidikan Pemuda Muslim, Bagi Para orangtua dan Dai), sebagaimana disampaikan oleh Budi Azhari ( 2013) .

Di pasal kedua, beliau memberi judul: Syabab Bukan Murohaqoh. Setelah mengkaji di pasal ini, beliau menyampaikan dengan tegas sudah waktunya kita membuang istilah murohaqoh (yang dalam bahasa kita: remaja). Dan menegaskan bahwa istilah yang jelas dipakai oleh Nabi adalah syabab (pemuda). Ini bukan sekadar pembahasan tentang istilah.
Tetapi ada nilai di balik istilah yang membuat beliau menolak hal tersebut.

Kata Al Murohaqoh dalam Bahasa Inggris disebut: the teenagers dan dalam bahasa kita dikenal dengan: usia remaja. Al Murohaqoh dalam kamus Arab bermakna: kedunguan dan kebodohan, kejahatan, dan kedzaliman, serta gemar melakukan kesalahan. Nampak jelas bahwa Arab yang kalah peradaban dari orangorang barat hari ini, ikut menamai usia emas dalam sejarah Arab dan Islam itu dengan istilah yang bermakna sekacau itu. Karena memang dalam berbagai definisi para ahli pendidikan dan psikologi hari ini, usia remaja identik dengan kekacauan, keguncangan, dan kenakalan.

Di usia ini, ada pembahasan tentang pubertas. Istilah pubertas jelas dari konsep hari ini. Inilah akar kata pubertas berikut definisinya. Menurut Monks (2002: 263), Pubertas adalah berasal dari kata puber yaitu pubescere yang artinya mendapat pubes atau rambut kemaluan, yaitu suatu tanda kelamin sekunder yang menunjukkan perkembangan seksual.

Root dalam Hurlock (2004), menyampaikan: Pubertas merupakan suatu tahap dalam perkembangan dimana terjadi kematangan alat-alat seksual dan tercapai kemampuan reproduksi. Ternyata kata puber mempunyai makna asli: rambut kemaluan. Selanjutnya digunakan untuk menandai fase mulia dari kehidupan manusia ini. 
Tidakkah kita melihat dengan kacamata Islam? Lihatlah masa remaja akhir, yang baru berakhir pada usia 19 tahun. Padahal kita semua tahu, usia tersebut adalah usia emas dan saat generasi muda muslim telah memiliki karya mulia di tengah masyarakat luas. Bahkan sebelum usia itu.

Itulah mengapa Rasulullah tidak pernah menyebut fase ini. Beliau mempunyai istilah sendiri: syabab. Kata ini dalam Bahasa Arab mempunyai akar makna, yaitu: kekuatan, baru, indah, tumbuh, awal segala sesuatu. Rasul langsung yang memilihkan bagi kita istilah untuk fase ini. Dengan makna penuh optimisme dan positif. Penuh harapan.

Setelah dikaji oleh para pakar muslim di bidang pendidikan, ternyata disimpulkan bahwa keguncangan dan kenakalan di usia ini bukan merupakan hal yang pasti dan harus dilalui oleh anak-anak kita.

DR. Majid 'Irsan al Kailani (Falsafah At Tarbiyah Al Islamiyah) berkata, adapun Al Murohaqoh bukan merupakan fenomena yang harus terjadi pada perkembangan usia manusia. Ini merupakan masalah yang mungkin dihindari sama sekali dalam kehidupan setiap pribadi. Al Murohaqoh adalah merupakan penyakit dari berbagai penyakit masyarakat kapitalis.

Hal yang serupa disampaikan oleh DR. Abdurahman al 'Aisawi (Sikolojiyah al Murohiq al Muslim al Mu'ashir):

Pertumbuhan seksual di usia Al
Murohaqoh tidak mesti menyebabkan krisis. Tetapi sistim masyarakat hari inilah yang bertanggung jawab terhadap krisis Al Murohaqoh. Sebagaimana yang disampaikan oleh Margareth Mead: Di masyarakat sederhana fase remaja ini tidak ada. Seseorang berpindah dari usia kanakkanak menuju usia dewasa secara langsung setelah upacara tradisional tertentu.

Teranglah bahwa fase remaja seharusnya tidak ada dalam perjalanan hidup pemuda Islam. Bahkan $\mathrm{Al}$ 'Aisawi menuliskan salah satu judul dalam bukunya tersebut: Mitos Badai (Usia Remaja). DR. Khalid Ahmad Asy Syantut (Tarbiyah Asy Syabab Al Muslim lil Aba' wad Du'at) juga menyebut Al Murohaqoh sebagai: Penyakit Jahiliyah Kontemporer.

Hal di atas juga diperkuat oleh literature psikologi, bahwa tidak semua tokoh psikologi sependapat dengan teori yang menunjukkan bahwa sebagian besar remaja mengalami krisis identitas, rapuh, gamang, dan memberontak, sebagaimana disebutkan Offer \& Schonert dalam (Lavesque 2014) :

Adolescent turmoil is an imprecise label applied to adolescents during the 1970s, and which proposed that adolescence universally involved a time of emotional turmoil of storm and stress (Larson and Ham 1993). Behavioral patterns or characteristics typically associated with this view of 
turmoil include rebelliousness, concern about identity and role, unstable moods, and unpredictable and highly mercurial behavior. This belief has since been disconfirmed, as Offer asserts that only a minority of adolescents experience adolescent turmoil (perhaps approximately 20\%) and adolescents typically sustain enjoyable relationships with their families and peers, and are comfortable with their social and cultural values (see Offer and Schonert-Reichl 1992)

\section{METODE PENELITIAN}

Metode penelitian ini menggunakan pendekatan kualitatif yaitu penyajian data dan analisis data menggunakan kata-kata dan simbolsimbol, bukan data statistik. Sebagai penelitian studi kasus, maka langkahlangkah yang digunakan adalah metode induktif, yaitu mengidentifikasi fenomena delinquen kemudian secara khusus mengidentifikasi faktor-faktor penyebab penganiayaan yang mengakibatkan kematian dengan wawancara mendalam serta mengumpulkan bukti-bukti dokumentasi, menganalisis secara terus-menerus sejak memasuki lapangan penelitian, menggambarkan realitas yang ada untuk menarik kesimpulan. Jadi, bersifat dari bawah ke atas (bottomup), dalam penelitian kualitatif teori yang dirumuskan disebut teori yang diangkat dari dasar atau grounded theory. Arikunto (2010: 23).

Dalam hal ini peneliti melakukan analisis terhadap aspek psikologis diri remaja (faktor endogin) dalam kasus penganiayaan yang menyebabkan kematian di Dusun Kayunan, Kecamatan Ngaglik, Kabupaten Sleman, dengan pendekatan teori perkembangan moral Kohlberg. Teknik analisis data dilakukan dengan Analisis Fenomenologi untuk menarik kesimpulan berdasarkan data yang diperoleh dan berdasarkan tujuan penelitian. Penelitian ini merupakan studi kasus yang belum tentu dapat digeneralisasi terhadap berbagai kasus yang serupa, akan tetapi dengan berpijak pada teori-teori umum yang berlaku, maka penelitian ini dapat menjadi bahan pertimbangan bagi kasus-kasus serupa di tempat yang berbeda.

Penelitian ini merupakan studi kasus, sehingga jumlah informan tidak ditentukan berdasarkan populasi. Setelah peneliti memperoleh key informan, maka peneliti berupaya memperoleh informan berikutnya dengan teknik "snow balling" sehingga dapat digali informasi secara terus-menerus dan sebanyakbanyaknya dari sumber yang benarbenar mengetahui informasi tersebut. Arikunto (2010: 24). 
Obesitas di Indonesia menjadi masalah yang serius dan diperlukan perhatian yang khusus. Dalam beberapa tahun terakhir masalah obesitas mengalami peningkatan. Data yang dikeluarkan kementerian kesehatan menunjukan persentase obsesitas pada perempuan maupun pria di 2007 sebesar 15\% namun pada 2016 jumlah obesitas mencapai 35\% (www.Mediaindonesia.com,

Februari 2017). Dalam peringatan hari obesitas sedunia tahun 2016 dengan tema "Calling For Urgent Goverment Action To end Child Obesity" bertujuan mendorong pemerintah dalam mengambil tindakan segera untuk menghentikan kenaikan obesitas pada tahun 2025 (www.almazia.com, 18 Februari 2017). Hal ini menunjukan bahwa obesitas merupakan masalah yang serius. Faktor utama yang menyebabkan seseorang mengalami obesitas adalah kebiasaan makan secara berlebihan atau pola makan yang salah.

Kebiasaan makan yang berlebihan atau pola makan yang salah berhubungan erat dengan kemampuan seseorang mengendalikan atau mengotrol dirinya. Menurut Mappiare (2006) mengontrol diri adalah kesadaran dan kemampuan individu dalam menahan diri dari berbagai stimuli atau rangsang yang dapat mempengaruhi efektivitas seseorang. Masalah obesitas menjadi urgen ketika dampak yang ditimbulkan begitu besar bagi seseorang seperti kecemasan, rendah diri, tidak percaya diri, menjadi sasaran bullying dan mengakibatkan depresi. Oleh sebab itu diperlukan upaya mengatasi obesitas.

Berdasarkan dari penyebab utama masalah obesitas yaitu kebiasaan makan yang berlebihan dan pola makan yang salah maka upaya yang dapat dilakukan adalah melalui intervensi yang berfokus pada perubahan perilaku. Intervensi yang digunakan dalam mengatasi masalah obesitas melalui teknik self-control.

Teknik self-control bertujuan menekankan pada aktivitas dari klien yang memungkinkan seseorang mengontrol dalam situasi-situasi problematiknya. Teknik self-control dalam mengatasi masalah obesitas meliputi prosedur: menspesifikasikan masalah dan menetapkan tujuan, membuat komitmen untuk berubah, mengambil data dan menilai penyebab-penyebab masalah, merancang penangan dan mengimplementasikan rencana penanganan dan mencegah kembalinya perilaku ke kondisi awal dan membuat pencapaian tujuan dapat bertahan lama (Martin \& Pear, 2015).

\section{PEMBAHASAN}

Pengertian Obesitas

Obesitas menurut Soetjiningsih (2012) adalah merupakan salah satu penyakit salah gizi sebagai akibat konsumsi makanan yang berlebihi kebutuhannya. Menurut Misnadierly 
(2007) obesitas adalah kelebihan lemak dalam tubuh, yang umumnya ditimbun dalam jaringan subkutan (bawah kulit), sekitar organ tubuh dan kadang-kadang terjadi perluasan ke dalam jaringan organ. Sedangkan menurut Sartika (2011) obesitas merupakan akibat keseimbangan energi positif untuk periode waktu yang cukup panjang. Sehingga obesitas adalah kelebihan lemak yang tertimbun dalam tubuh akibat mengkonsumsi makanan terlalu berlebihan.

\section{Klasifikasi Obesitas}

Menurut Mansjoer (dalam Sudargo dkk, 2014) obesitas di bagi menjadi dua yaitu: obesitas primer dan obesitas sekunder. Obesitas primer adalah obesitas yang disebabkan oleh faktor gizi dan berbagai faktor yang mempengaruhi masukan makanan dan obesitas sekunder adalah obesitas yang disebabkan oleh adanya penyakit atau kelainan.

\section{Faktor Penyebab Obesitas}

Obesitas memiliki beberapa faktor penyebab, menurut Proverawati (2010) faktor resiko terjadinya obesitas antara lain: Faktor genetik, obesitas diturunkan oleh faktor genetik, dalam terbentuknya obesitas didalam keluarga tidak hanya berbagi gen tetapi makan dan kebiasaan gaya hidup. Faktor lingkungan, gen merupakan faktor penting dalam timbulnya obesitas, tetapi lingkungan memegang peranan yang cukup berarti yaitu perilaku dan pola gaya hidup contohnya dalam mengatur makanan yang di konsumsi dan berapa kali makan dalam sehari.

Faktor psikososial, apa yang ada dalam pikiran dapat mempengaruhi kebiasaan makannya. Banyak orang yang memberikan reaksi terhadap emosinya dengan makanan. Salah satu bentuk gangguan emosi adalah persepsi yang negatif. Gangguan emosi ini merupakan masalah serius pada penderita wanita muda penderita obesitas, dan dapat menimbulkan kesadaran yang berlebihan tentang kegemukannya serta rasa tidak nyaman dalam pergaulan sosialnya.

Faktor kesehatan, ada beberapa penyakit yang mengakibatkan terjadinya obesitas seperti hipotiroidisme, sindroma chusing, sindroma prader-willi dan beberapa kelainan saraf yang dapat menyebabkan orang menjadi banyak makan. Faktor perkembangan, penambahan ukuran dan jumlah selsel lemak menyebabkan bertambahnya jumlah lemak yang disimpan dalam tubuh. Penderita obesitas terutama yang menjadi gemuk pada masa kanak-kanak dapat memiliki sel lemak lima kali lebih banyak dibandingkan dengan orang yang normal, jumlah sel-sel lemak tidak dapat dikurangi oleh karena itu penurunan berat badan hanya dapat dilakukan dengan cara mengurangi jumlah lemak dalam setiap sel. Aktivitas fisik, seseorang dengan aktivitas fisik yang kurang dapat meningkatkan prevalensi 
terjadinya obesitas. Orang-orang yang kurang aktif memerlukan kalori dalam jumlah yang sedikit dibandingkan dengan orang yang aktif.

\section{Dampak obesitas}

Menurut Vivi (2006) dampak obesitas dapat terjadi dalam jangka panjang maupun jangka pendek yaitu:

1) Gangguan psikososial, rasa rendah diri, depresif dan menarik diri dari lingkungan. Hal ini disebabkan penderita obesitas sering menjadi korban olok-olokan teman-temannya. Dapat pula karena ketidakmampuan untuk melaksanakan suatu tugas atau kegiatan akibat adanya hambatan pergerakan oleh obesitas, 2) Pertumbuhan fisik atau linier yang lebih cepat dan usia tulang yang lebih lanjut dibandingkan usia biologisnya, 3) Masalah ortopedi akibat beban tubuh yang terlalu berat, 4) Gangguan pernafasan seperti infeksi saluran nafas, tidur ngorok, sering mengantuk siang hari.

\section{Konsep Teknik Self-Control}

Menurut Nevid, Rathus \& Greene (2005) teknik self-control adalah membantu individu yang bermasalah mengembangkan keterampilan yang dapat mereka gunakan dalam untuk mengubah perilaku mereka. Menurut Martin \& Pear (2015) teknik self-control adalah sebuah teknik pengendalian perilaku yang mengakibatkan sebuah perubahan bagi perilaku yang dikendalikan. Sehingga teknik self- control adalah sebuah teknik yang bertujuan membantu individu mengontrol atau mengatur perilakunya.

\section{Prinsip-Prinsip Teknik Self-Control}

Ada beberapa persyaratan yang perlu diperhatikan dalam menggunakan teknik self-control yaitu berkaitan dengan subjek itu sendiri atau lingkungan subjek. Menurut Walker (dalam Purwanta, 2015) perilaku subjek yang akan memprakarsai pengelolaan diri harus memenuhi lima hal yaitu:

1. Sasaran perilaku harus dinyatakan dengan jelas.

2. Perilaku alternatif sebagai treatment perlu diidentifikasi kemungkinan keterlaksanaannya dalam jangkauan subjek.

3. Perilaku pilihan harus ditawarkan kepada subjek, lebih diutamakan perilaku yang diusulkan oleh subjek. Dalam bagian ini prinsip premac harus diterapkan sebagai pengukuh.

4. Tujuan treatment harus dapat diamati dengan jelas dan dapat diukur.

5. Subjek harus diberikan kemudahan dalam berkonsultasi manakala memerlukan bantuan dalam mengavaluasi atau melaksanakan treatment.

\section{Langkah-langkah \\ Penerapan Teknik Self-Control Dalam Mengatasi Obesitas}


Menurut Martin \& pear (2015) dalam menerapkan teknik self-control ada beberapa langkah-langkah yang harus diterapkan:

1. Menspesifikasikan masalah dan menetapkan tujuan

Dalam penerapan teknik selfcontrol perlu dilakukan spesifikasi masalah terlebih dahulu kemudian menetapkan tujuan. Untuk mengetahui penyebab pasti perilaku dan tujuan yang ingin dicapai, ada beberapa langkah sebagai proses penajaman yaitu: a) Tuliskan tujuan, b) Buatlah daftar hal-hal yang ingin di katakan atau lakukan yang dapat mengidikasikan dengan jelas sudah memenuhi tujuan tersebut, c) Pada kelompok individu dengan tujuan yang sama dengan anda, bagaimana anda bisa memutuskan siapa yang sudah memenuhi tujuan tersebut dan siapa yang tidak, d) Jika tujuan itu merupakan produk perilaku seperti menurunkan berat badan atau obesitas, buatlah daftar perilaku spesifik yang dapat membantu meraih produk tersebut.

2. Membuat komitmen untuk berubah

Komitmen untuk berubah merujuk kepada pernyataanpernyataan atau tindakantindakanyang mengindikasikan bahwa penting sekali untuk mengubah perilaku, dan mendapat manfaat dari melakukannya dan siap melakukan mengupayakan hal tersebut dengan komitmen.
Keberhasilan mengubah perilaku mensyaratkan adanya tindakan-tindakan untuk menjaga komitmen itu tetap kuat dengan melakukan:

a. Daftarlah semua manfaat yang akan diterima setelah mengubah perilaku.

b. Nyatakan secara publik komitmen untuk berubah yaitu menjadikan beberapa oang sebagai saksi komitmen.

c. Menata ulang lingkungan anda dapat menyediakan pengingat yang cukup sering bagi komitmen dan tujuan. Tujuan dapat di perkuat dengan menempelkan pada stiker atau catatan di tempat-tempat yang sering dikunjungi seperti pintu kulkas, meja belajar atau kendaraan. Semua pengingat ini berkaitan dengan manfaat positif meraih tujuan.

d. Investasikan sejumlah waktu dan energi untuk merancang proyek yang terbaik. Siapkan daftar pernyataan yang berkaitan dengan investasi anda di proyek tersebut yang dapat anda gunakan untuk menguatkan dan mepertahankan komitmen.

e. Karena anda pasti menghadapi godaan untuk menghentikan proyek anda, rancanglah caracara menghadapi godaannya.

3. Mengambil data dan menilai penyebab-penyebab masalah 
Mengambil data terkait kemunculan perilaku bermasalah. Kapan, dimana dan seberapa sering muncul. Ini sangat penting ketika tujuan adalah menurunkan perilaku berlebihan contohnya obesitas. Ada sejumlah alasan mengapaharus mencatat karakteristik perilaku bermasalah, salah satunya untuk menyediakan titik acuan atau garis dasar bagi pengevaluasian kemajuan.

Untuk masalah obesitas, catatan bisa dibuat setiap kali ingin mengkonsumsi makanan secara berlebihan sehingga perilaku itu sendiri yang menguatkan pencatatan atau dapat menyiapkan penguat eksternal yang dikontrol orang lain misalnya dengan meminta teman-teman menguatkan perilaku catatan dengan: a) Memberitahu mereka proyek modifikasi perilaku, b) Selalu membawa catatan dan grafik rekaman perilaku atau menempelkan ditempat yang mudah diakses untuk mendapatkan umpan balik, c) Melaporkan secara teratur proyek dan hasilnya.

4. Merancang dan mengimplementasikan rencana penangan

Dalam hal ini ada dua hal yang bisa di implementasikan melalui mengelola anteseden dan mengelola konsekuensi. Mengelola anteseden yaitu mengontrol perilaku melalui: a. Instruksi, menyatakan bahwa setiap program modifikasi diri mestinya mencangkup instruksi diri.

b. Modeling, perilaku yang dimodelkan yaitu kelas lain dari peristiwa-peristiwa stimulus yang berguna di dalam program pengendalian diri.

c. Panduan fisik, pemodifikasian perilaku menggunakan panduan fisik untuk mengarahkan individu bergerak ke perilaku yang diinginkan.

d. Lingkungan sekitar, strategi yamg efektif dalam memodifikasi perilaku sendiri adalah menata ulang lingkungan sekitar agar tidak lagi menghadirkan petunjukpetunjuk perilaku bermasalah.

e. Orang lain, mengamati model termasuk salah satu cara yang mampu menyediakan dorongan kuat bagi kita untuk terlibat dalam sejumlah perilaku.

f. Waktu dalam sehari, Kadang dimungkinkan meraih pengendalian diri yang sukses dengan mengubah waktu aktivitas.

g. Operasi motivasi, kejadiankejadian yang mempengaruhi kekuatan konsekuensi sebgai penguat atau penghukum, sehingga pada gilirannya perilau dipengaruhi oleh 
konsekuensi-konsekuensi tersebut.

h. Kriteria penguasaan, sebuah persyaratan bagi performa untuk mempraktikkan sebuah keterampilan sehingga kriterianya terpenuhi, perilaku tersebut berarti sudah terpelajari.

Mengelola konsekuensi adalah strategi yang dilakukan dalam mengelola konsekuensi melalui:

a. Mengeliminasi penguat tertentu yang tanpa disengaja sudah menguatkan perilaku tak diinginkan di situasi spesifik.

b. Mencatat dan menggrafikkan perilaku target.

c. Menerima penguat spesifik ketika memperlihatkan perbaikan atau bahkan hanya dengan bertahan diprogram.

5. Mencegah kembalinya perilaku bermasalah dan membuat pencapaian tujuan anda bertahan lama

Strategi untuk mencegah kemunduran adalah dengan mengenali penyebab yang memungkinkan dan sejumlah langkah untuk meminimkannya. Kemunduran disebabkan dua hal antara lain:

a. Penyebab kemunduran akibat anteseden, yaitu

1) Kemerosotan anteseden yang dapat dihindari.

2) Kemerosotan anteseden yang tak tak terelakan.
3) Reaksi berlebihan terhadap kemerosotan sesekali.

4) Percakapan-diri yang kontra produktif.

b. Penyebab kemunduran akibat spesifikasi respons, yaitu:

1) Perilaku target yang tidak jelas.

2) Perilaku target yang terlalu lama jangkanya.

3) Mencoba terlalu banyak dalam waktu yang singkat.

4) Gagal memadukan penghargaan sehari-hari ke dalam program.

5) Konsekuensi menjadi signifikan hanya setelah terakumulasi

6) Strategi tambahan untuk membuat hasil program bertahan lama.

\section{SIMPULAN}

Dalam mengatasi masalah obesitas dengan strategi penerapan teknik self-control dapat dilakukan dengan langkah-langkah yaitu: menspesifikasikan masalah dan mentapkan tujuan, membuat komitmen untuk berubah, mengambil data dan menilai penyebab-penyebab masalah, merancang dan mengimplementasikan rencana penanganan dan mencegah kembalinya perilaku ke kondisi awal dan membuat pencapaian tujuan anda bertahan lama. 


\section{DAFTAR PUSTAKA}

Greene, B., Nevid, Jeffrey S., \& Rathus, Spencer. 2005. Psikologi Abnormal. Jakarta: Erlangga.

Mappiare, Andi. 2006. Kamus Istilah Konseling \& Terapi. Jakarta: Rajawali Pers.

Martin, G. Pear, J. 2015. Modifikasi Perilaku Makna dan Penerapannny. Yogyakarta: Pustaka Pelajar.

Misnadiarly. 2007. Obesitas Sebagai Faktor Resiko Beberapa Penyakit. Jakarta: Pustaka Obor Populer.

Proverawati, Atika. 2010. Obesitas dan Gangguan Perilaku Makan Pada Remaja. Yogyakarta: Nuha Medika.

Purwanta, Edi. 2015. Modifikasi Perilaku. Yogyakarta: Pustaka Pelajar.

Sartika, Ratu Ayu Dewi. 2011. Faktor Obesitas Pada anak 5-15 Tahun di Indonesia. Depok: Departemen Gizi Kesehatan Masyarakat, FKM UI.

Soetjningsih. 2012. Tumbuh kembang Remaja dan Permasalahannnya. Jakarta: Sagung seto.

Sudargo, Toto, dkk. 2014. Pola Makan dan Obesitas. Yogyakarta: Gadjah Mada University Press.
Vivi, R. 2006. Karakteristik Penderita Diabetes Mellitus dengan Komplikasi yang Rawat Inap di RSUP. H. Adam Malik Tahun 2006. Medan: Skripsi. Tidak terbit.

www.almazia.com.diakses 18 februari 2017.

www.MediaIndonesia.com. diakses 18 Februari 2017. 